\title{
Level of Adoption of Cow Cut Insemination Implementation UPSUS SIWAB In Soppeng District
}

\author{
Andi Syastiawan, Ahmad Ramdhan, Sitti Nurani \\ Agribusiness Study Program, Graduate School Hasanuddin University, Makassar,90245, Indonesia
}

Received date: 12 February 2019, Accepted date: 15 May 2019, Online date: 3 June 2019

\author{
Address for Correspondence: \\ Andi Syastiawan, Agribusiness Study Program, Graduate School Hasanuddin University, Makassar,90245, Indonesia \\ E-mail: andisyastiawan@pasca.unhas.ac.id
}

Copyright $(9) 2019$ by authors and American-Eurasian Network for Scientific Information.

This work is licensed under the Creative Commons Attribution International License (CC BY).

http://creativecommons.org/licenses/by/4.0/

\section{(C) (1) Open Access}

\begin{abstract}
The background of the government's efforts to increase the production and productivity of beef cattle, therefore the government (Ministry of Agriculture) issued a policy to encourage accelerated increase in production for meat availability, through the implementation of SIWAB UPSUS that farmers are expected to be able to quickly adopt these activities. The SIWAB UPSUS consists of artificial insemination and INKA (natural mating), on the implementation of UPSUS SIWAB Artificial Insemination in the regency soppeng the birth data is not in line with the government's expectations, therefore the adoption of the SIWAB Artificial UPSUS Insemination study was conducted as an important indicator of the successful birth of the SIWAB UPSUS implementation. Purposing research is knowing the ability to adoption UPSUS SIWAB in Soppeng District. The population used is all beef cattle that participate in the UPSUS SIWAB program in Soppeng Regency. Respondent samples in identifying farmer adoption in the SIWAB UPSUS Artificial Insemination program involved 30 farmers who conducted UPSUS SIWAB Artificial Insemination in Liliriaja sub-district for direct interviews with a purposive sampling system. The writing of this thesis uses quantitative methods.

Research Results overall adoption rate of farmers to UPSUS SIWAB Artificial Insemination program in Liliriaja sub-district Soppeng district, with variable indicators of time needed by farmers adopting UPSUS SIWAB artificial insemination, benefits and quality of SIWAB UPSUS Insemination program and the range of application of Artificial Insemination to produce class interval weights 166 points and are in the medium category.
\end{abstract}

KEYWORDS

UPSUS SIWAB, Artificial Insemination, adoption, soppeng

\section{INTRODUCTION}

The development of livestock sub-sector in Indonesia needs to be improved, this needs to be considered for livestock products in Indonesia in general to increase from year to year. This is contrary to the challenges of the community's nutritional needs but is not balanced with an increase in livestock population. Therefore, there is a need to increase the production and population of beef cattle. The productivity of beef cattle is strived to be increased as optimal as possible. Intensive pattern of beef cattle business has used intensive technology. By opening technology, capital, and resources to get optimal results [1] In the development of beef cattle, in 2016 the government issued a UPSUS SWAB program policy, the UPSUS SIWAB Program was a manifestation of the government's commitment to increase beef cattle population and as a target for meat sufficiency in 2026. 
Revy Alviany et al., 2019. Level of Adoption of Cow Cut Insemination Implementation UPSUS SIWAB In Soppeng District /American-Eurasian Journal of Sustainable Agriculture. 13(2): 85-91. DOI: 10.22587/aejsa.2019.13.2.10

The program is believed to lead Indonesia to achieve beef self-sufficiency in 5-10 year ahead. Beef cattle can be maximized by their potential to produce calves and become a government program focused on increasing beef cattle production through the implementation of artificial insemination assistance in cattle [2].

The success of UPSUS SIWAB insemination can be observed at the level of farmer adoption of the program. Beef cattle raising effort is an attempt to improve productivity beef as optimally as possible. Cattle business with an intensive pattern had used technologies intensively. By combining technology, capital, and resources in order to obtain optimum output [3] Therefore, the socio-economic and psychological variables substantially influencing the technology adoption of different enterprises must be taken into consideration while accelerating the pace of technology adoption under diversified farming system [4] That farmers adopts an innovation if they expect it to contribute to better achieving their goals with, which may include economic, social and environmental aspects, while considering risk-related issues at the same time [5,6] Technology can affect its users and adoption rates. The characteristics of the technology itself are also an important influence on farmers' technology adoption and usage decisions. The impact of the influence and cost of technology on farmers' adoption. In this context, the risk preferences of farmers are also important in influencing the technology adoption decision, especially if capital-intensive technology costs are irreversible

\section{MATERIALS AND METHODS}

Determine the level of adoption of farmers in responding to and following the SIWAB UPSUS Artificial Insemination program using sub-variables:

1) The time needed by farmers starts from receiving information on the implementation of the SIWAB IB UPSUS until it is implemented with indicators 0-5 months, 5-10 months and more than 10 months.

2) The benefits and quality of the IB UPSUS SIWAB program with measurement indicators are very know, know but do not understand, do not know.

3) The range of the application of IB to cattle breeders with indicators of converting whole livestock, as little as a little. To determine the level of adoption of UPSUS SIWAB Artificial Insemination in Liliriaja Subdistrict, Soppeng Regency uses the basic assumption of interval, as follows:

Highest score $=3 \times 30=90$ points

The lowest score $=1 \times 30=30$ points

Class Range $\quad=$ Highest number - lowest number

$$
\begin{aligned}
& =\frac{90-30}{3} \\
& =20 \text { point }
\end{aligned}
$$

From the above values, it can be made a response method as follows:

Height $=70-90$

Medium $=50-69$

Low $\quad=30-49$

The basic assumptions for class interval assessment are as follows:

Highest score $=$ Highest weight $\mathrm{x}$ Number of samples $\mathrm{x}$ Number of questions

$$
=270
$$

Lowest score $=$ lowest weight $\mathrm{x}$ number of samples $\mathrm{x}$ number of questions

$$
=90
$$

Class range $=\underline{\text { highest number }- \text { lowest number }}$

$$
\begin{aligned}
& =\frac{270-90}{3} \\
= & 60
\end{aligned}
$$

From the above values, an answer category can be made as follows:

1. Low $=90-149$

2. Medium $=150-209$

3. Height $=210-270$ 
Revy Alviany et al., 2019. Level of Adoption of Cow Cut Insemination Implementation UPSUS SIWAB In Soppeng District /American-Eurasian Journal of Sustainable Agriculture. 13(2): 85-91. DOI: 10.22587/aejsa.2019.13.2.10

Based on the results of research obtained about the assessment of innovation adoption regarding the time needed by farmers starting from the receipt of information on the implementation of SIWAB UPSUS Artificial Insemination until its implementation can be seen in table 1.

Table 1. Assessment of farmers against the adoption of UPSUS SIWAB artificial insemination innovations regarding the time required by farmers

\begin{tabular}{llccc}
\hline No & \multicolumn{1}{c}{ Indicator } & Farmers & Persentase & Weight \\
\hline Time needed by farmers & & & & \\
information received began until & 3 & 17 & 56,66 & 51 \\
the implementation of IB UPSUS & 2 & 3 & 10.01 & 6 \\
SIWAB in Liliriaja sub-district & 1 & 10 & 33,33 & 10 \\
& & 30 & 100 & 67 \\
\hline
\end{tabular}

Source: Primary Data processed, 2019

Based on table 1, the time needed by farmers to adopt the implementation Artificial Insemination of UPSUS SIWAB reaches 67 weight numbers with the medium category vulnerable, the participation rate of farmers adoption Artificial Insemination of UPSUS SIWAB in Liliriaja sub-district takes around 5-10 months to carry out artificial insemination because farmers need time to determine the choice of artificial insemination by looking at the results that were cleaned by Artificial Insemination, if the results were satisfactory the farmer decided to take part in the SIWAB UPSUS Artificial Insemination program. This is consistent with the income of who thinks that the psychological behavior of farmers influences the adoption of new technologies. That is, their tendency to adopt new technologies follows trends, and imitates each other [7]. Other factors that lead to the adoption of breeders in artificial insemination have not reached high grade levels due to the risks borne by farmers if the parent of Artificial Insemination experiences death defects due to the application of technology Artificial insemination is a new thing for cattle breeders.

Figure 1. Assessment of adoption of Artificial Insemination Technology (IB) innovation regarding the time needed by farmer farmers to receive information until its application to Bali cattle farms in Liliriaja sub-district, Soppeng district.

Note:

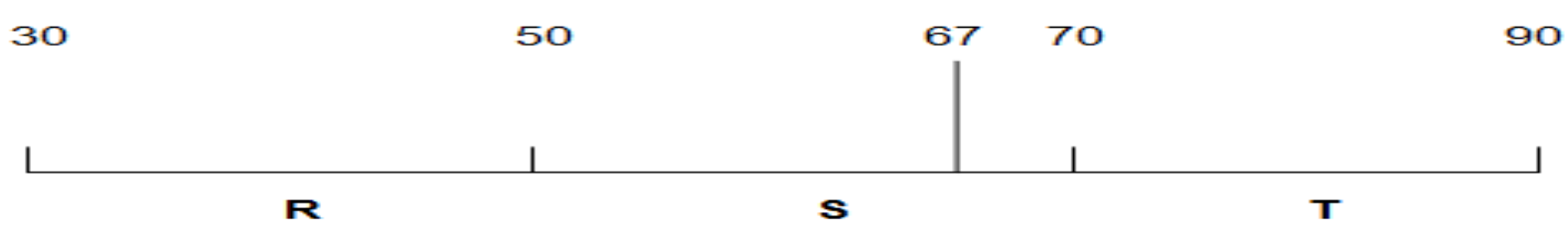

Height $=70-90$

Medium $=50-69$

Low $\quad=30-49$

Figure 2, the assessment of adoption Artificial Insemination technology of UPSUS SIWAB regarding the time needed by farmers to receive information until its application to beef cattle farms in the Liliriaja subdistrict of Soppeng Regency has a score of 67 between 50 and score of 70 on a medium scale (5-10 months). This is the focus of the local government actively conducting counseling to farmer groups about the benefits of artificial insemination and the advantages of technology implementation Artificial insemination is more effective than natural mating. [8] states that one that influences innovation adoption is the intensity of counseling. Agricultural extension agents act as bearers of the mission to convey ideas, new things to the user, namely farmers and their families. The more active the instructor promotes an innovation it can be expected that the higher level and speed of adoption of the innovation.

\section{Benefits and Quality of SIWAB UPSUS Artificial Insemination Program}

Benefits and quality of the Insemination made by UPSUS SIWAB can be seen in the respondents' weight of knowledge about the quality of Artificial Insemination in the form of better success and birth rates and the benefits of implementing UPSUS SIWAB program. Based on the results of research obtained on the assessment of adoption regarding the benefits and quality of SIWAB UPSUS Artificial Insemination in Liliriaja sub-district, Soppeng district can be seen in table 2 . 
Revy Alviany et al., 2019. Level of Adoption of Cow Cut Insemination Implementation UPSUS SIWAB In Soppeng District /American-Eurasian Journal of Sustainable Agriculture. 13(2): 85-91. DOI: 10.22587/aejsa.2019.13.2.10

Table 2. Assessment of farmers on the adoption of innovations in the benefits and quality of artificial insemination of upsus siwab in Liliriaja sub-district soppeng district

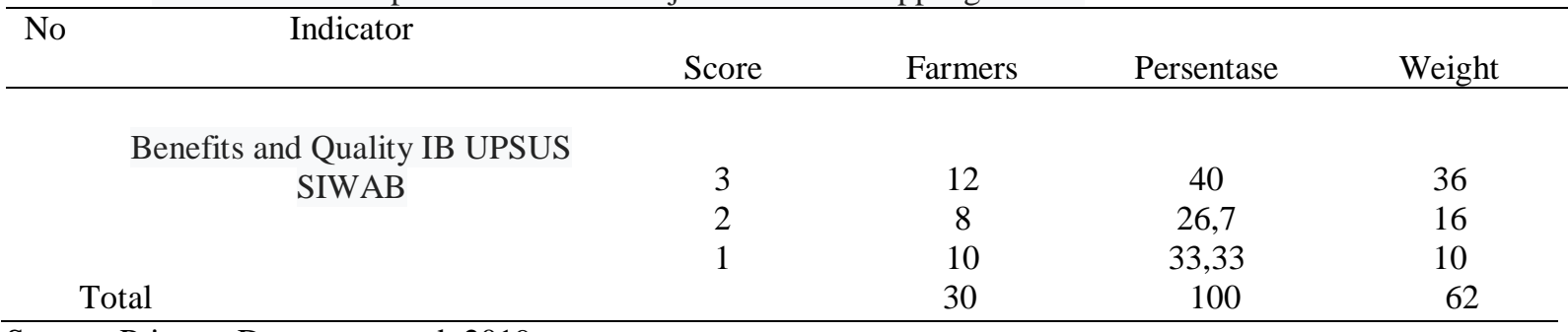

Source: Primary Data processed, 2019

In table 5, the farmer's assessment of the adoption of benefits and the quality artificial insemination of UPSUS SIWAB concluded the respondents' weighting scores reached 62, with the moderate category at the class interval. This shows that overall the farmer knows about the benefits and quality artificial insemination of UPSUS SIWAB, because the information provided by the government gives attraction to farmers who understand artificial insemination to join the SIWAB UPSUS program. A very influential benefit to the adoption of breeders is that the program is provided in subsidized assistance by UPSUS SIWAB in the form of artificial insemination without paying fees from farmers. Farmers who adopt artificial insemination know the quality of IB births, which is good cow growth and increased meat productivity especially in the application of Artificial Insemination can use Cross Breeding seeds to increase productivity of meat weight. Showing that with IB, both crossing and refining, has increased beef cattle production [9]. This is indicated by the perceptions of respondents who stated that (1) cattle birth weight is greater IB results, (2) IB cattle yield is greater than natural mating cows, $67.9 \%$ agree and $29.6 \%$ strongly agree, (3) average daily gain of cows from IB results are relatively higher than those of natural mating cows, $66.7 \%$ agree and $26.7 \%$ strongly agree, and (4) at the same age, cows IB results are heavier compared to cows from natural mating. The role of the government in managing the program is very necessary for the role of extension agents to deliver information - information on the development of beef cattle breeding and specifically the benefits and quality of the application of artificial insemination technology and extension of lust detection in livestock as the right step to be adopted by farmers. That counseling is one of the factors that influence the level of adoption, where extension agents play an active role in spreading innovation into a social system [10].

Figure 2. Assessment of adoption of Artificial Inemination Technology innovations regarding the benefits and quality of SIWAB UPSUS Artificial Insemination

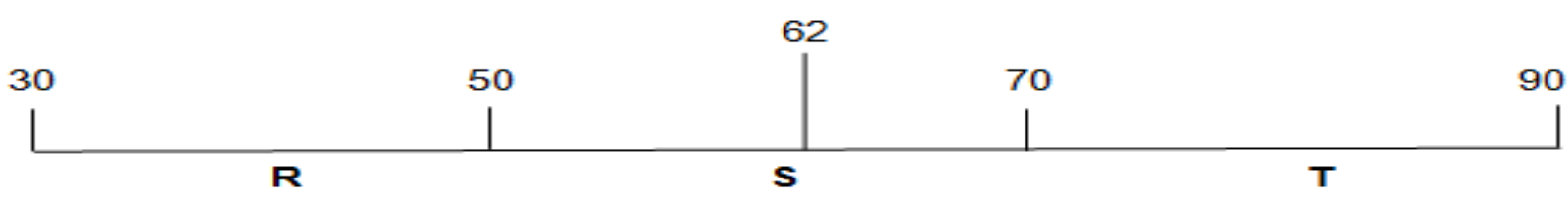

Source: Primary Data processed, 2019

Note:

Height $=70-90$

Medium $=50-69$

Low $=30-49$

Figure 2, the assessment of the adoption of benefits and quality of Insemination made by UPSUS SIWAB in the district of Liliriaja in Soppeng district has a score of 61 which is between the scores of 50 and 70 on a medium scale. The results of the study were preceded by the results of the study the adoption rate of IB beef cattle farmers in Lalabata sub-district concluded that the quality of IB by comparing the application with the recommendations delivered by extension agents was: Farmers implementing recommendations or recommendations that delivered by the instructor in seeing the signs of cows having lust and applying IB to livestock (+) agreeing at 100\% which means high IB quality [11].

Reach the application of Artificial Insemination to cattle breeders 
Revy Alviany et al., 2019. Level of Adoption of Cow Cut Insemination Implementation UPSUS SIWAB In Soppeng District /American-Eurasian Journal of Sustainable Agriculture. 13(2): 85-91. DOI: 10.22587/aejsa.2019.13.2.10

Extensive application is the application of IB technology to the number of cattle populations owned by beef cattle farmers. Based on the results of research obtained on the assessment of innovation adoption regarding the wide application of artificial UPSUS SIWAB in Liliriaja district, Soppeng district can be seen in table 3

Table 3. Farmers' assessment of Adoption of Artificial UPSUS SIWAB Insemination in the District Liliriaja Kab. Soppeng

\begin{tabular}{ccccc}
\hline No & & & & \\
& Score & Farmers & Persentase & Weight \\
\hline Area of Application of IB & & & & \\
UPSUS SIWAB in the Lililiriaja & 3 & 12 & 40 & 36 \\
Sub-districtSoppeng District & 2 & 8 & 26,7 & 16 \\
Total & 1 & 10 & 33,33 & 10 \\
\hline
\end{tabular}

Source: Primary Data processed, 2019

In table 3, it can be seen that the total score of adoption of technological innovations regarding the broad application of Artificial Insemination (IB) on beef cattle farms in the Liliriaja sub-district of Soppeng district is $32 \%$, in the low category. This shows that the widespread application of IB activities in the Liliriaja sub-district is that overall the farmers have carried out these activities but not all of the livestock they maintain apply Artificial Insemination (IB) technology. This is because there are still many breeders who use the natural mating system compared to using IB because farmers are afraid to take risks and most farmers are still in the stage of trying the technology on a small scale. This is in accordance with the opinion of which states that problems commonly found at the farm level are afraid of taking risks if they fail [10]. The research results differed from the results of the study the level of adoption of artificial insemination of beef cattle breeders in the Kuranji sub-district which stated the extent of the application of IB to female livestock, among others: Farmers only use IB for some farmers (-) disagree $100 \%$, which means that artificial insemination has been applied by farmers in the sub-district [12].

Figure 3. Assessment of the adoption of UPSUS SIWAB Artificial Insemination regarding the wide application of beef catle Farms in Liliriaja sub-district, Soppeng district

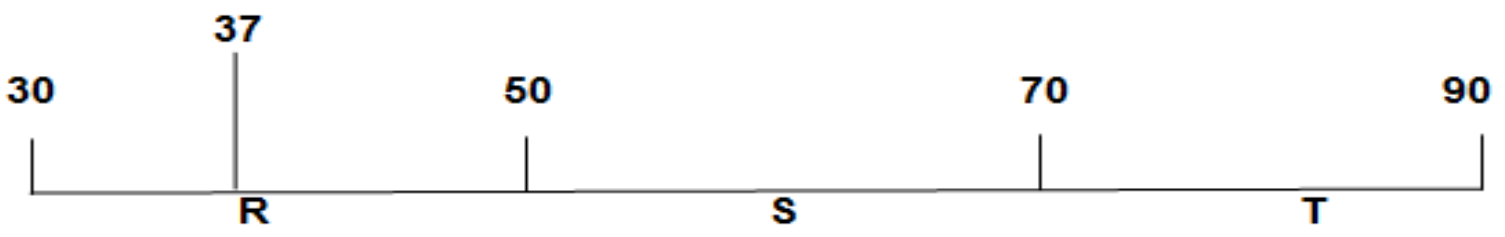

Source: Primary Data processed, 2019

Note:

Height $=70-90$

Medium $=50-69$

Low $=30-49$

In figure 3 about Artificial Insemination of UPSUS SIWAB assessment regarding the extent of application to beef cattle farms in the Liliriaja sub-district of Soppeng district scored 37 in between 30 and 50 in the low scale category.

\section{Level of Adoption of the whole implementation of UPSUS SIWAB Artificial Insemination}

The results of the research obtained about the response of farmers in adopting the implementation of the Insemination program made by UPSUS SIWAB beef cattle farms in the Liliriaja sub-district of Soppeng district can be seen in table 3 
Revy Alviany et al., 2019. Level of Adoption of Cow Cut Insemination Implementation UPSUS SIWAB In Soppeng District /American-Eurasian Journal of Sustainable Agriculture. 13(2): 85-91. DOI: 10.22587/aejsa.2019.13.2.10

Table 4. The overall level of adoption of farmers for the implementation of SIWAB UPSUS Artificial Insemination in Liliriaja sub-district Soppeng district

\begin{tabular}{|c|c|c|c|}
\hline No & Description & Score & Persentase $(\%)$ \\
\hline 1 & $\begin{array}{l}\text { Time needed for adoption } \\
\text { Benefits and quality of IB }\end{array}$ & 67 & 40.4 \\
\hline 2 & UPSUS SIWAB & 62 & 37.4 \\
\hline 3 & Application of the SIWAB IB UPSUS & 37 & 22.2 \\
\hline \multicolumn{2}{|r|}{ Total } & 166 & 100 \\
\hline
\end{tabular}

Source: Primary Data processed, 2019

Based on table 4, it can be seen that the number of weights from the adoption level of SIWAB UPSUS Artificial Insemination is 166 points. These results indicate that in receiving information on the implementation artificial insemination program of UPSUS SIWAB, beef cattle breeders in Liliriaja sub-district, Soppeng district are in the moderate category, because in the medium category is the farmer category, not all have adopted artificial insemination technology of UPSUS SIWAB because farmers still use natural mating systems and most farmers apply the technology on a small scale for fear of the risk of death and disability in breeders. Stating that farmers are experimenting with new ideas called on a small scale if the experiment is successful then the farmer will try it on a wider scale [13].

Figure 5. Value of Adoption Level of farmers in the implementation Artificial Insemination of UPSUS SIWAB program in Liliriaja sub-district Soppeng district

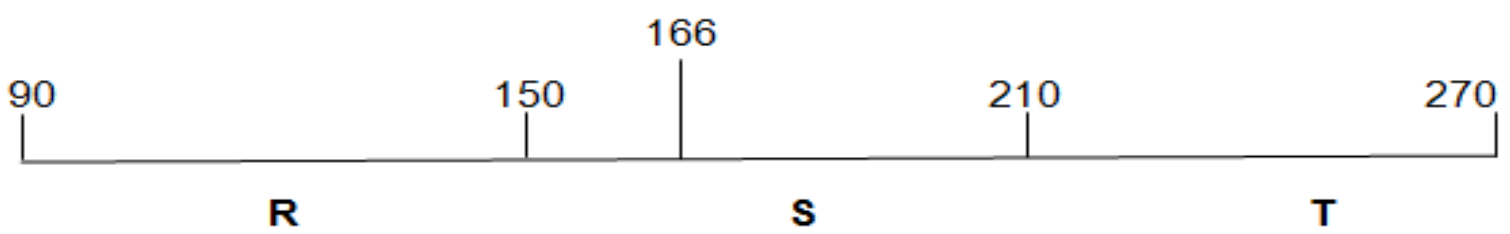

Source: Primary Data processed, 2019

Based on Figure 4, it can be seen that the weight value obtained from the study is 166 points which means it is in the medium category. Beef cattle breeders in the district of Liliriaja, Soppeng district are still hesitant to implement the UPSUS SIWAB Artificial Insemination technology because there are still many villages in the sub-district of Liliriaja that have not been reached by Inseminator officers. Artificial insemination and some breeders who have carried out UPSUS SIWAB artificial insemination want to try and see the real results of artificial insemination and after succeeding in the experiment it will apply Artificial Insemination to livestock on a larger scale. The stage of trying, farmers or individuals are faced with a real problem. It must be real, pouring out his thoughts about the new idea in the real situation [13]. That thought must be put into practice, according to what is called the stage of trying out a new idea, how it does it, why should it do it, with whom it does the new idea, whether it is done alone or in groups and where he has to do the experiment. For this reason, sometimes it takes help from other parties who are more competent so that the effort to experiment with the new idea on a small scale is still successful. If this experiment is successful and the farmer will try to do it on a wider scale, then the stage is called the adoption stage. The results of this study are in accordance with the results of previous studies beef cattle breeders in the Lalabata district of Soppeng district trying the information they have obtained and taking into account the advantages and disadvantages and faced with a real problem and he try it on a small scale [10].

\section{CONCLUSION}

The overall level of adoption of farmers for UPSUS SIWAB Artificial Insemination program in Liliriaja subdistrict Soppeng district, with variable indicators of time needed by farmers adopting UPSUS SIWAB artificial insemination, benefits and quality Insemination program of UPSUS SIWAB and the range of application of Artificial Insemination to produce class interval weights 166 points and are in the MEDIUM category. 
Revy Alviany et al., 2019. Level of Adoption of Cow Cut Insemination Implementation UPSUS SIWAB In Soppeng District /American-Eurasian Journal of Sustainable Agriculture. 13(2): 85-91. DOI: 10.22587/aejsa.2019.13.2.10

\section{REFERENCE}

[1] Sirajuddin,S.N. Lestari, V.S danFadliah, N.S. 2012. PerbandinganPendapatanPeternakSapi Bali yang Melakukan Program InseminasiBuatan (IB) dan Tidak Melakukan Program InseminasiBuatan (IB) di Kec. SoppengRiajaKabupatenBarru (Farmer Income Comparisson of AI and on-AI Programme Participants at SoppengRiaja, Barru-South Sulawesi)

[2] Kementerian Pertanian. 2016. Peraturan Menteri Pertanian Republik Indonesia Nomor:48/Permentan/Pk.210 /10/2016 tentang Upaya Khusus Percepatan Peningkatan Populasi Sapi dan Kerbau Bunting. Jakarta (Indonesia): Kementerian Pertanian

[3] Sirajuddin, S.N., A. Asnawi, I. Rasyid, A. Mangalisu, Masnur, 2016. Competitiveness of Beef Cattle Fattening in Kulo Sub district, Sidrap District South Sulawesi Province. Advances Environmental of Biology (AEB) Journal., 10(1): 171-175

[3] Abdullah, A. 2008. Peranan penyuluhan dan kelompok tani ternak untuk meningkatkan adopsi teknologi dalam peternakan sapi potong, Procedings seminar nasional sapi potong 24 November 2008. Palu

[4] Singha, A.K., M.J. Baruah, R. Bardoloi, P. Dutta, U.S. Saikia, 2012. Analysis on Influencing Factors of Technology Adoption of Different Land Base Enterprises of Farmers under Diversified Farming System. Journal of Agricultural Science, 4(2): 139-145.

[5] Greiner, R.L. Patterson and O. Miller, 2008. Mptivations,risk perceptions and adoption of conservation practices by farmers. Agricultural Systems (in press)

[6] Malaiki, R., B. Sinsin, L. Parrot, J. Lanqon, A. Floquet and N. Lutaladio, 2016. Suistanable Agriculture and Innovation Adoption in a Small-Scale Food Production System: the Case of Yam in Rotation with Intercropping Mucuna pruriens var utilis and Maize in the Guinea-Sudan Zone of Benin. America nEurasian J.Agric.\&Environ.Sci., 16(1): 70-84.

[7] Lydia Devaga Bahar. 2017. Willingness To Pay Peternak Terhadap Adopsi Teknologi Inseminasi Buatan Pada Sapi Bali. Tesis Penelitian Program Study Pasca Sarjana Agribisnis Universitas Hasanuddin, Makassar.

[8] Soekartawi. 2005. Agroindustri DalamPerspektifSosialEkonomi. Raja Grafindo Persada. Jakarta.

[9] Mursyid, M. 2011. Implikasi Kebijakan Pembibitan Sapi terhadap Adopsi Inovasi Inseminasi Buatan Peternak Sapi Potong, Tesis. Sekolah Pasca Sarjana Institut Pertanian Bogor, Bogor.

[10] Rogers , E.M., R.F. Shoemaker. 1971. Communication of innovation, Second Edition. The Free Press, New York

[11] AnggaNugraha, Agustina Abdullah dan Nurani Sirajuddin. 2016. Peneltian Tingkat adopsi inovasi teknologi Inseminasi Buatan pada peternakan sapi potong di Kecamatan Lalabata Kabupaten Soppeng..

[12] Demita, Soekartawi, 2002. Prinsip Dasar Ekonomi Pertanian. Penerbit Rajawali Prdess, Jakarta.A, 2011. Adopsi inovasi Inseminasi Buatan pada peternak sapi potong di Kecamatan Kuranji. Skripsi. Fakultas Peternakan, Universitas Andalas, Padang.

[13] Soekartawi. 2002. Prinsip Dasar Ekonomi Pertanian. Rajawali Press, Jakarta. 